\title{
A profile of the impact of Acta Botanica Brasilica: reflections on how to improve visibility and recognition of a scientific journal
}

\author{
Fabio Rubio Scarano ${ }^{1,2,3}$, Karen De Toni ${ }^{1}$ and Cristiana Vasconcellos Goulart Amarante ${ }^{1}$
}

Received: March 30, 2009. Accepted: May 14, 2009

\begin{abstract}
A profile of the impact of Acta Botanica Brasilica: reflections on how to improve visibility and recognition of a scientific journal). We have estimated the ISI-impact factor of Acta Botanica Brasilica for the past six years, calculated the journal's $h$-index, calculated the journal's self-citation, examined country and institutions of origin of the papers that cite Acta papers, and examined scope and profile of the most-cited papers published by the journal. Results demonstrated a steep rise in impact factor and citation frequency in 2008, which is most encouraging, but also revealed that the journal is below the level of maturity expected of a 20 -year old journal. Visibility of the journal is mostly national although, surprisingly, journal's self-citation of $12 \%$ is fairly low. We use Acta as an example to discuss possible strategies to enhance the international visibility of botanical journals that are newcomers to ISI.
\end{abstract}

Key words: $h$-index, impact factor, scientometrics, self-citation

RESUMO - (Um perfil do impacto da Acta Botanica Brasilica: reflexões acerca de como aumentar a visibilidade e o reconhecimento de um periódico científico). Este artigo estima o fator de impacto (ISI-Web of Science) do periódico Acta Botanica Brasilica para os últimos seis anos, calcula o índice- $h$ do periódico, calcula a sua auto-citação, examina os países e instituições de origem dos artigos que citam artigos da Acta, e examina o escopo e o perfil dos artigos mais citados ao longo da história do periódico. Os resultados demonstraram um aumento substancial no fator de impacto estimado e na freqüência de citação em 2008, o que é muito encorajador, mas também revelaram que o periódico está abaixo do grau de maturidade esperado para um periódico com 20 anos de existência. A visibilidade do periódico é predominantemente nacional embora, surpreendentemente, a auto-citação de $12 \%$ seja consideravelmente baixa. A revista é utilizada como exemplo para discutir possíveis estratégias para aumentar a visibilidade internacional de periódicos em botânica recém-indexados no ISI.

Palavras-chave: auto-citação, cientometria, fator de impacto, índice $h$

\section{Introduction}

The impact factor of a journal in a given year is calculated as the number of citations it receives in that year to papers it published in the two preceding years divided by the number of citable items published during these two years (Garfield 2007). The adequacy of this tool to evaluate journal's quality and performance raises passionate controversy (Nature Editors 2005), but remains a key analytical parameter driving authors' choice of where to allocate their outputs as well as driving the choice of sponsors and funding agencies of where to allocate their money. More recently, the $h$-index proposed by Hirsch (2005) raised immediate excitement (although it is not free from criticism; Grace 2007) as a tool that could better evaluate individual career performance than citation frequency (number of citations) only. It is calculated as the number of papers of a given author that has received each at least the same number of citations. For instance, an author with $h=10$

\footnotetext{
1 Instituto de Pesquisas Jardim Botânico do Rio de Janeiro, Diretoria de Pesquisa Científica, Rua Pacheco Leão 915, Jardim Botânico, 22460-280 Rio de Janeiro, RJ, Brasil

2 Universidade Federal do Rio de Janeiro, CCS, IB, Departamento de Ecologia, C. Postal 68020, 21941-970 Rio de Janeiro, RJ, Brasil

3 Corresponding Author: fscarano@biologia.ufrj.br
} 
has 10 papers that were at least cited 10 times each. It was soon followed by journal $h$-indices, often by simply transposing calculations for individual authors to a journal (Braun et al. 2006; Schubert 2007). Thus, a given journal with $h=10$ has 10 papers that were at least cited 10 times each within a given time frame.

Acta Botanica Brasilica (Acta bot. bras.) has recently qualified to receive an impact factor by Thomson-ISI (formerly Institute for Scientific Information) Web of Science (ISI thereof). Therefore, it will soon list in JCR (Journal of Citation Reports). This fact places the journal at the core of the so-called 'impact factor game' (PLoS Medicine Editors 2006), which is a legitimate drive to continually increase impact factor so as to achieve higher visibility and recognition. It has been recently claimed that such an attitude is of great national interest, particularly considering the strategic value of biodiversity for Brazil (Scarano 2008). The journal's indexation in ISI has the additional benefit of allowing direct access to citation frequencies of papers in ISI database. Thus, in this paper we used this tool to estimate: (1) the impact factor of Acta Botanica Brasilica in years prior to indexation and a projection of its 2008 impact factor, so as to evaluate journal's progress in terms of visibility; (2) the origin of the papers that cite Acta Botanica Brasilica (which journals and which countries) assessing the proportion of self-citation by papers published in Acta itself; and (3) the current $h$-index of Acta Botanica Brasilica to assess its maturity as a journal. Moreover, (4) the papers that contribute to the journal's $h$-index where each examined in relation to the papers that cite them. In addition to this profile description, the discussion is directed to provoke a reflection about strategies that emerging botanical journals, such as the case studied here, might use so as to achieve higher visibility.

\section{Materials and methods}

Calculation of the impact factor of Acta Botanica Brasilica was made for years 2003, 2004, 2005, 2006, 2007 and 2008, following the formula mentioned in the Introduction. Thus, the 2008 impact factor, for instance, was given by the number of papers published in this journal in 2006 and 2007 that were cited by ISI indexed journals divided by the number of citable items in Acta for that period, which consist of all papers published in the journal during 2006 and 2007. It is worth mentioning at this point that 2002 was the year when the journal began to publish four numbers per year. So, the 2003 impact factor is calculated upon a much lower denominator than all the other years, as will be seen later. The number of papers citing Acta papers, as well as their sources, titles and abstracts, were obtained by using the Cited Reference Search mode of Web of Science at http://apps.isiknowledge.com/WOS_CitedReferenceSearch as assessed by the Portal de Periódicos da CAPES (www.capes.gov.br). Once cited reference mode was assessed, in the cited work field, due to the distinct types of abbreviations used by authors that cite the journal, we typed Acta Bot* Bras* to search for impact factor and $h$-index. For impact factor of each year, the filter for year option was used. For instance, to calculate the impact factor for 2003, year limits were given using the cited year field starting at 2001 and finishing at 2002, and in the timespan field we typed 2003. Then, in each case, the papers cited that were published in 2002 and 2001 were marked, which allowed us to see, for each of them, how many and which papers cited them in that year. The number of papers published per year was counted directly at the journal's homepage (www.scielo.br).

The survey of the ISI-indexed journals that most cite Acta papers in 2008 and their countries of origin was also made using the Cited Reference Search mode of ISI, as described earlier. The list of cited authors was marked (select all) and the search finalized (finish search). We then used the Analyze Results option, which allowed access to data regarding the journals that most cite Acta and the country of origin of the authors.

The $h$-index of the journal was calculated as an adaptation of $h$-index for authors, as the number of papers published in the journal, since its first issue in 1988, which received at least an equal number of citations since then. Although we are aware of the new $g$-index (Egghe 2006) proposed as an improvement on the $h$-index, we used the latter since in its conception (Hirsch 2005) it was also proposed that it could be objectively used to assess scientific maturity, which would be achieved when $h$-index is at least equal to the number of years of the author's career (for instance, an author with a 20-year career has reached maturity level if his/her $h$-index is 20). In this paper we assume that the maturity level proposed by Hirsch (2005) for authors is applicable to groups (e.g., research institutions, journals and even nations; Schubert 2007; Arencibia-Jorge et al. 2008) in order to assess Acta's maturity level. Steps to calculate the journal's $h$-index followed those described for impact factor, after direct counting of the records on Feb. $20^{\text {th }}$, 2009 and correcting the spelling of names of authors and/or dates whenever necessary.

We have also assessed author self-citation of the most cited papers that contribute to the journal's $h$-index and journal self-citation. The author self-citation of a paper is given by the number of citations made by the author himself or his co-authors on that paper divided 
by the total number of citations received by the paper (Glänzel et al. 2006). Journal self-citation was calculated as the number of citations to Acta papers made by papers published in Acta divided by the total number of citations to Acta within a given time-frame.

\section{Results}

Table 1 displays an estimate of the impact factors based on ISI data for Acta Botanica Brasilica. It shows a marked raise in the journal's impact in 2008, which is probably one of the reasons that gained indexation in ISI. After a drop in 2004, related to an increase in the number of papers published by the journal that was not followed by an increase in the citation of these papers, the impact factor raised steadily in the following years up to the point where it had an almost three-fold increase from 2007 to 2008. However, although this is an encouraging result, a quick comparison with other broadscope botanical journals (Tab. 2) reveals that Acta has plenty of room for improvement.

During the existence of the journal from 1988 to 2008 it received 733 citations, $60 \%$ of which were written in English, 36\% in Portuguese, 3\% in Spanish and less than $1 \%$ in German. In 2008 alone, the journal received a total of 236 citations, which adds up to $32 \%$ of all its citations in history (the reader must not get confused with the number in Tab. 1 that refers to 2006 and 2007 papers cited in 2008). Of the 25 institutions that cited Acta's papers in 2008 only two are not Brazilian: New York Botanical Garden (ranked 24 ${ }^{\text {th }}$ ) and Universidad de Buenos Aires (ranked $25^{\text {th }}$ ). Of these 236 citations of Acta papers, 175 are papers that have only Brazilian authors (74.2\%), 21 have at least one Brazilian author $(8.9 \%)$ and $40(16.9 \%)$ have only foreign authors. Table 3 shows the journals where the citations of Acta's papers during 2008 came from. Nearly 12\% are selfcitations (Acta papers that cite other Acta papers) and out of the 13 journals that cited Acta in 2008 eight are Brazilian-based. Table 4 further confirms the regional reach of the journal, since the origin of most authors citing it in 2008 was Brazil by a large margin. Among the 21 papers with collaboration between Brazilians and foreign authors, U.S.A., Germany and Argentina add up to c. $71 \%$ of the affiliation of partners, while among the 40 papers with no Brazilian authors, U.S.A., Germany, Mexico and Venezuela add up to $55 \%$ of the source of the contributions.

The $h$-index of the journal is 10 , which means that at least 10 papers (more precisely 11) published in the journal since its first issue, in 1988, were cited at least 10 times each by ISI-indexed papers. Table 5 shows which papers these are and provide some information about them. The main patterns that emerge from this table are as follows: 1 ) papers are in average (mean \pm stdev) $14.3 \pm 6.7$ years old (and the deviation is entirely due to three papers with high proportion (> 30\%) of self-citation or citation by a single research group; data

Table 1. Impact factors for Acta Botanica Brasilica estimated from ISI database.

\begin{tabular}{ccccc}
\hline $\begin{array}{c}\text { Year of } \\
\text { citation (A) }\end{array}$ & $\begin{array}{c}\text { Years of } \\
\text { publication (B) }\end{array}$ & $\begin{array}{c}\text { Number of } \\
\text { citations (C) }\end{array}$ & $\begin{array}{c}\text { Number of papers } \\
\text { published in B (D) }\end{array}$ & $\begin{array}{c}\text { Impact } \\
\text { factor IF }=\text { C/D }\end{array}$ \\
\hline 2008 & $2006-7$ & 50 & 177 & 0.282 \\
2007 & $2005-6$ & 20 & 188 & 0.106 \\
2006 & $2004-5$ & 18 & 190 & 0.094 \\
2005 & $2003-4$ & 7 & 91 & 0.048 \\
2004 & $2002-3$ & 5 & 77 & 0.054 \\
2003 & $2002-1$ & 9 & & 0.116 \\
\hline
\end{tabular}

Table 2. Impact factor of ISI-JCR for 2007 of international botanical journals with a thematic scope that is as broad as that of Acta Botanica Brasilica. Rank is established from a total of 152 journals indexed in the Botany field (*rank not given in the journal's homepage).

\begin{tabular}{|c|c|c|c|}
\hline Journal & Country & Impact factor & Rank \\
\hline Acta Botanica Brasilica (2008 projection) & Brazil & 0.232 & $*$ \\
\hline American Journal of Botany & U.S.A. & 2.512 & 26 \\
\hline Australian Journal of Botany & Australia & 0.987 & $*$ \\
\hline Botanical Journal of the Linnean Society & U.K. & 1.075 & 79 \\
\hline Flora & Germany & 1.157 & $*$ \\
\hline South African Journal of Botany & South Africa & 0.444 & $*$ \\
\hline
\end{tabular}


not shown), which indicates a low level of short-term impact; (2) authors, topics or biomes where the studies are located are mostly varied (although strictly within Brazilian borders, and with a surprising absence of the Atlantic and Amazon rain forests among the most cited papers) and reflect the broad scope of the journal and its national reach; (3) self-citation is mostly low $(<20 \%)$

Table 3. The ISI-indexed journals that most cited Acta Botanica Brasilica's papers in $2008(\mathrm{n}=236)$.

\begin{tabular}{lcr}
\hline Source title & Record count & $\%$ \\
\hline Acta Botanica Brasilica & 28 & 11.86 \\
Cerne & 11 & 4.66 \\
Mycotaxon & 10 & 4.24 \\
Revista Árvore & 7 & 2.97 \\
Botanical Journal of the Linnean Society & 6 & 2.54 \\
Brazilian Journal of Biology & 6 & 2.54 \\
Ciência Florestal & 6 & 2.54 \\
Flora & 6 & 2.54 \\
Journal of Ethnopharmacology & 6 & 2.54 \\
Annals of Botany & 5 & 2.12 \\
Brazilian Archives of Biology and Technology & 5 & 2.12 \\
Ciência Rural & 5 & 2.12 \\
Pesquisa Agropecuária Brasileira & 5 & 2.12 \\
\hline
\end{tabular}

or absent, however citation by few (three or less; data not shown) research groups predominates; (4) all but one paper was written in Portuguese.

\section{Discussion}

Recent indexation in ISI and many of the features revealed by the set of results presented here should be a strong encouragement for authors, readers and editors of Acta Botanica Brasilica. The journal's visibility and recognition is increasing, as shown by its calculated impact factor that nearly tripled from 2007 to 2008, and the high number of citations in 2008 as compared to the past 20 years of existence of the journal. However, the journal's current profile also demands reflection (see, for instance, Albuquerque 2009) and effective action on a number of aspects so as to bring it to a high international standard of visibility. It also serves as an interesting case study for other emerging journals in Brazil and elsewhere which aspire to enhance international visibility.

If we assume that the maturity level proposed by Hirsch (2005) for authors is applicable to journals (Schubert 2007), Acta's $h$-index of 10 is well below

Table 4. Country of affiliation of the authors that cited Acta Botanica Brasilica papers in 2008. In this analysis we considered all authors and not only the corresponding author or the first author.

\begin{tabular}{lrr}
\hline Country & Record count & $\%$ of 236 records \\
\hline Brazil & 196 & 83.05 \\
U.S.A. & 17 & 7.20 \\
Germany & 10 & 4.24 \\
Mexico & 5 & 2.12 \\
Argentina & 4 & 1.69 \\
England, France, Spain, Venezuela & 3 each & 1.27 each \\
Australia, Canada, Japan, Pakistan & 2 each & 0.85 each \\
Belgium, Chile, Colombia, Costa Rica, Cuba, Czech Republic, Iran, Netherlands, Poland, Switzerland, & 1 each \\
\multicolumn{2}{r}{ Thailand, Turkey, Uruguay } & 0.42 each \\
\hline
\end{tabular}

Table 5. Most cited papers of Acta Botanica Brasilica that are responsible for the journal's $h$-index of 10 , and some of their main characteristics. Language: P - Portuguese; E - English

\begin{tabular}{|c|c|c|c|c|c|c|}
\hline Year & Main authors & Number of citations & Self-citations & Main topic & Biome & Language \\
\hline 1990 & Giulietti \& Hensold & 25 & 0 & Biogeography & various & $\mathrm{P}$ \\
\hline 1996 & Luque et al. & 19 & 1 & Anatomy & - & $\mathrm{P}$ \\
\hline 1988 & Araujo \& Oliveira & 18 & 0 & Floristics & restinga & $\mathrm{P}$ \\
\hline 2003 & Alcoforado Filho et al. & 16 & 2 & Phytosociology & caatinga & $\mathrm{P}$ \\
\hline 2005 & Albuquerque et al. & 14 & 12 & Ethnobotany & caatinga & $\mathrm{E}$ \\
\hline 2002 & Albuquerque \& Cavalcanti & 13 & 12 & Ethnobotany & caatinga & $\mathrm{P}$ \\
\hline 1989 & Pott et al. & 11 & 1 & Aquatic macrophytes & pantanal & $\mathrm{P}$ \\
\hline 1993 & Mantovani \& Martins & 11 & 2 & Floristics & cerrado & $\mathrm{P}$ \\
\hline 1989 & Nascimento \& Cunha & 11 & 2 & Phytosociology & pantanal & $\mathrm{P}$ \\
\hline 1988 & Giulietti et al. & 10 & 2 & Ethnobotany & cerrado & $\mathrm{P}$ \\
\hline 1988 & Felfili et al. & 10 & 4 & Phytosociology & cerrado & $\mathrm{P}$ \\
\hline
\end{tabular}


the maturity level expected for a 20 -year old journal (which would be $h=20$ ). Moreover, Acta's most cited papers are not highly cited by international standards. The direct comparison of impact factors with other international, broad-scoped botanical journals (as in Tab. 2) is also revealing in that sense. Two factors seem to contribute to this pattern: (1) the journal's reach is mostly regional; and (2) papers of the journal do not have short-term impact. Although a nation-oriented bias in citation is to be expected (Pasterkamp et al. 2007), the c. $83 \%$ of citations by Brazilian authors is a very high proportion by any standard. Interestingly, however, the journal's self citation (Acta papers that cite Acta papers) of $12 \%$ as verified for year 2008 is at the lower limit expected (Glänzel et al. 2006). Thus, increasing international visibility to promote a higher proportion of foreign citations and increasing visibility of the journal by Acta authors themselves, to increase journal's self-citation within the average range (10 to $30 \%$ ) should both help increase Acta's impact factor. If we assume that the low journal self-citation found for 2008 in Acta as a consistent pattern, it could perhaps be explained in one or more of three ways: (1) papers published in Acta are unappealing to Acta's authors; (2) Acta's authors do not read Acta; (3) Acta's authors are biased against citing Acta's papers. Since Acta is a journal run by a scientific society, all three explanations seem unlikely and this pattern, therefore, demands further investigation.

Low immediate impact, as seen by the citation pattern of Acta's most cited papers, is the second factor contributing to the low impact factor mentioned above. This is not entirely typical for biodiversity-related fields such as Botany and Ecology, as it is often informally suggested. They are respectively $11^{\text {th }}$ and $13^{\text {th }}$ out of 24 disciplines in terms of the ratio long-term to current (two-year based) impact factor (Contreras et al. 2006). In addition to the need to attract highly original papers, a common strategy to achieve immediate citation is the publication of opinion papers and review papers (Scarano 2008).

Papers based on international partnerships, with authors of different nationalities, also tend to increase journal's visibility and impact factor. Therefore, it is not surprising that of the four countries that most cite Acta papers, two are among the countries that most cite Brazil when all fields are examined together (Mexico and Argentina), and the other two are traditional partners in Botany (U.S.A. and Germany) (Schubert \& Glänzel 2006).

When we focus our analysis on the most cited papers of Acta two other interesting patterns emerge. First, it can be said that Acta does stand out as a typical broad-scope national journal, since among the most cited papers there is a thematic diversity covering various botanical disciplines and, more importantly, there is a very good regional cover. Second, the result that only one among the 11 most cited was written in English can be misleading, since it could either be interpreted that language matters little to impact or that had they been written in English their number of citations would have been higher.

Finally, another interesting datum is the drop in impact that followed the increase in number of papers published annually by the journal in 2004. It reveals that the journal should be cautious in expanding the number of papers per issue or even increasing the number of issues per year. To establish a fixed number of papers to be published per year or an average rejection rate (in both cases, irrespective of number of papers submitted) are common procedures to many journals.

\section{Final remarks}

The data shown in this paper reveals that Acta has historically had a national focus and that its recent increase in visibility indicates that there is a growing demand for Brazilian-built knowledge on botanical issues, both nationally and internationally. This follows an overall trend of increase in scientific output and visibility of Brazilian science as a whole, which is strongly backed up by the federal agencies that finance and evaluate scientific production and graduate training (Scarano 2007), including in their support of national journals. Thus, Acta should aim for an increasing international reach, while focusing on Brazilian scientific issues that are of worldly interest. This calls for a number of initiatives (some of which are already in course), which might include for instance incentive for publications in English, preference for papers with a potentially higher immediate impact (including original, review and opinion papers) and an overall more strict editorial policy.

Although we do agree that it is legitimate to journals within given fields of knowledge to pursue an exclusively national audience (Meneghini et al. 2006), we clearly think this should not be the case of Acta Botanica Brasilica - the first Brazilian botanical journal to be indexed in ISI. Further, we do not think that Botany should be seen as a domestic field of knowledge, since biodiversity represents a key resource for humanity and Brazil strategically holds within its territory a significant proportion. Thus, the set of recommendations for enhanced visibility displayed in this paper, might serve other botanical journals in Brazil and elsewhere, particularly in biodiversity-rich countries, that are still below maturity level. 


\section{Acknowledgements}

We thank M.M. Fiuza-de-Melo, O. Yano and P. Windisch for relevant comments and criticism to the manuscript. The first author thanks Conselho Nacional de Desenvolvimento Científico e Tecnológico-CNPq (the Brazilian Research Council) for a productivity grant.

\section{References}

Albuquerque, U.P. 2009. A qualidade das publicações científicas considerações de um Editor de Área ao final do mandato. Acta Botanica Brasilica 23: 292-296.

Albuquerque, U.P.; Andrade, L.H.C. \& Silva, A.C.O. 2005. Use of plant resources in a seasonal dry forest (northeastern Brazil). Acta Botanica Brasilica 19: 27-38.

Albuquerque, U.P. \& Andrade, L.H.C. 2002. Conhecimento botânico tradicional e conservação em uma área de caatinga no estado de Pernambuco, Nordeste do Brasil. Acta Botanica Brasilica 16: 273-285.

Alcoforado Filho, F.G.; Sampaio, E.V.S.B. \& Rodal, M.J.N. 2003. Florística e fitossociologia de um remanescente de vegetação caducifólia espinhosa arbórea em Caruaru, Pernambuco. Acta Botanica Brasilica 17: 287-303.

Araujo, D.S.D. \& Oliveira, R.R. 1988. Reserva Biológica Estadual da Praia do Sul (Ilha Grande, Estado do Rio de Janeiro): lista preliminar da flora. Acta Botanica Brasilica 1(supl.): 83-94.

Arencibia-Jorge, R.; Barrios-Almaguer, I. \& Fernández-Hernández, S. 2008. Applying successive h-indices in the institutional evaluation: a case study. Journal of the American Society for Information Science and Technology 59: 155-157.

Braun, T.; Glänzel, W. \& Schubert, A. 2006. A Hirsch-type index for journals. Scientometrics 69: 169-173.

Contreras, C.; Edwards, G. \& Mizala, A. 2006. The current impact factor and the long-term impact of scientific journals by discipline: a logistic diffusion model estimation. Scientometrics 69: 689-695.

Egghe, L. 2006. Theory and practice of the $g$-index. Scientometrics 69: 131-152.

Garfield, E. 2007. The history and meaning of the Journal Impact Factor. Journal of the American Medical Association 295: 90-93.
Giulietti, A.M. \& Hensold, N. 1990. Padrões de distribuição geográfica dos gêneros de Eriocaulaceae. Acta Botanica Brasilica 4: 133-159.

Giulietti, N.; Giulietti, A.M.; Pirani, J.R. \& Menezes, N.L. 1988. Estudos em sempre-vivas: importância econômica do extrativismo em Minas Gerais. Acta Botanica Brasilica 1: 179-193.

Glänzel, W.; Debackere, K.; Thijs, B. \& Schubert, A. 2006. A concise review of the role of author self-citations in information science, bibliometrics and science policy. Scientometrics 67: 263-277.

Grace, J. 2007. The best papers are the boldest. Frontiers in Ecology and the Environment 5: 49-50.

Hirsch, J.E. 2005. An index to quantify an individual's scientific output. Proceedings of the National Academy of Sciences 102: 16569-16572.

Luque, R.; Sousa, H.C. \& Kraus, J.E. 1996. Métodos de coloração de Roeser (1972) - modificado - e Kropp (1972) visando a substituição do azul de astra por azul de alcião $8 \mathrm{GS}$ ou $8 \mathrm{GX}$. Acta Botanica Brasilica 10: 199-212.

Mantovani, W. \& Martins, F.R. 1993. Florística do cerrado na reserva biológica de Moji Guaçu, SP. Acta Botanica Brasilica 7: 33-60.

Meneghini, R.; Mugnaini, R. \& Packer, A.L. 2006. International versus national oriented Brazilian scientific journals. A scientometric analysis based on SciELO and JCR-ISI databases. Scientometrics 69: 529-538.

Nascimento, M.T. \& Cunha, C.N. 1989. Estrutura e composição florística de um cambarazal no Pantanal de Poconé, MT. Acta Botanica Brasilica 3: 3-23.

Nature Editors. 2005. Not-so-deep impact. Nature 435: 1003-1004.

Pasterkamp, G.; Roitmans, J.I.; de Kleijn, D.V.P. \& Borst, C. 2007. Citation frequency: a biased measure of research impact significantly influenced by the geographical origin of research articles. Scientometrics 70: 153-165.

PLoS Medicine Editors. 2006. The impact factor game: it is time to find a better way to assess scientific literature. Public Library of Science Medicine 3(6): e291. [http://medicine.plosjournals.org].

Pott, V.J.; Bueno, N.C.; Pereira, R.A.C.; Salis, S.M. \& Vieira, N.L. 1989. Distribuição de macrófitas aquáticas numa lagoa na fazenda Nhumirim, Nhecolândia, Pantanal, MS. Acta Botanica Brasilica 3(supl.): 153-168.

Scarano, F.R. 2007. Perspectives on biodiversity science in Brazil. Scientia Agricola 64: 439-447.

Scarano, F.R. 2008. Why publish? Revista Brasileira de Botânica 31: $189-194$.

Schubert, A. 2007. Successive h-indices. Scientometrics 70: 201-205. 